\title{
SPOTTED
}

\section{Spotted around the web: Social learning, cannabidiol, autism research dollars}

BY JILL ADAMS

10 DECEMBER 2021 